\title{
Effects of zinc deficiency on food intake and feeding patterns of rats
}

\author{
By J. K. CHESTERS AND J. QUARTERMAN \\ Rowett Research Institute, Bucksburn, Aberdeen $A B{ }_{2}{ }_{9} S B$
}

(Received 5 March 1970-Accepted 5 fune 1970)

\begin{abstract}
I. The effects of alterations of the protein and zinc concentrations of a semi-synthetic diet on the food intake and dietary preferences of $\mathrm{Zn}$-deficient and normal rats have been compared.

2. The voluntary food intake of $\mathrm{Zn}$-deficient rats fell to $70 \%$ of that of the controls. The day-to-day variation of intake increased markedly and was associated with a cyclical pattern of food consumption. When the food intake of deficient rats was slightly restricted the troughs of the cycles disappeared.

3. Concurrent with the fall in food intake, $\mathrm{Zn}$-deficient rats ceased to gain weight, but a similar change was found with pair-fed controls.

4. Force-feeding $\mathrm{Zn}$-deficient rats with $\mathrm{I} 40 \%$ of their voluntary intake rapidly induced signs of ill-health.

5. Reduction of the protein content of the diet from 20 to $5 \%$ resulted in an increased food intake and the disappearance of the cyclical pattern of intake. Growth, however, was not renewed.

6. Zn-deficient rats responded to a $\mathrm{Zn}$-supplemented diet within $\mathrm{I}-2 \mathrm{~h}$ by an increased food intake.

7. $\mathrm{Zn}$-deficient rats were able to discriminate between diets containing 6 and $x \mathrm{ppm} \mathrm{Zn}$ when both diets were offered simultaneously.

8. The responses of $\mathrm{Zn}$-deficient rats to $\mathrm{Zn}$-containing diets did not occur if the diets did not contain protein.
\end{abstract}

Although the first observable signs of $Z n$ deficiency are loss of appetite and failure to grow, these changes generally receive only passing comment in papers describing the clinical or biochemical lesions of the deficiency. In view of their prompt appearance in $\mathrm{Zn}$ deficiency in a variety of animal species it is likely that these changes are closely related to the primary lesions of the deficiency and may well be the only overt manifestation in mild deficiency states (Williams \& Mills, 1970). Accordingly, we have investigated the patterns of growth and food intake during the early stages of $\mathrm{Zn}$ deficiency and have studied the influence of dietary composition upon these patterns and on their reversion to normal during subsequent rehabilitation with $\mathrm{Zn}$. Some of the findings have been reported briefly (Humphries \& Quarterman, 1968).

\section{EXPERIMENTAL}

Hooded Lister rats of the Rowett Institute strain were used in all the experiments. They were kept in Perspex-and-glass cages; the deficient rats were fed from glass pots and the controls from the continuous-feeding devices described by Quarterman, Williams \& Humphries (1970).

The rats were generally weaned at $2 \mathrm{I}-23 \mathrm{~d}$ on to a $\mathrm{Zn}$-supplemented semi-synthetic diet, which served the dual purpose of accustoming the rats to the diet and allowing them to grow to the weight required before starting the experimental regimen. The 
semi-synthetic $\mathrm{Zn}$-deficient diet was based on sucrose, egg albumen and arachis oil with supplements of necessary vitamins and minerals (Williams \& Mills, 1970) and contained no more than $0.9 \mathrm{ppm} \mathrm{Zn}$. The supplemented diet contained $40 \mathrm{ppm} \mathrm{Zn}$, added as $\mathrm{ZnSO}_{4}$. Diets containing less than $20 \%$ protein were prepared by substituting maize starch for protein. For force-feeding, the diet was suspended in distilled water and dispersed by subjecting the suspension to 2 min ultrasonication at $2 \times 10^{4} \mathrm{~Hz}$ at $80 \mathrm{~W}$ to give a final concentration of $0.7 \mathrm{~g}$ dry matter $/ \mathrm{ml}$. The resultant slurry was force-fed to the rats in $2 \cdot 2 \mathrm{ml}$ quantities at five equally spaced intervals during each $24 \mathrm{~h}$ period.

For comparison of treatment effects on deficient and control animals, the $\mathrm{Zn}$-supplemented rats were individually 'pair-fed' with members of the deficient group.

\section{RESULTS}

\section{Growth and food intake of normal rats}

Expt $\mathrm{I}$. In anticipation of later studies of the influence of dietary $\mathrm{Zn}$ concentration on food consumption and of the effects of dietary composition on this relationship, the first experiment was undertaken to provide information on the food consumption of rats offered the $\mathrm{Zn}$-supplemented basal diet for periods corresponding to those to be employed during later experiments. Since the 'weight plateau' of rats in which growth had been arrested by the $\mathrm{Zn}$-depletion technique described above was at approximately $80 \mathrm{~g}$, information was particularly required on mean food intake and the day-to-day variation of the amount consumed by normal male rats of approximately that weight.

Four male rats were fed ad lib. on the $\mathrm{Zn}$-supplemented diet during growth from 60 to $120 \mathrm{~g}$, a range which adequately covered the weight range of the rats to be used in subsequent experiments, and their body-weights and food consumptions were determined daily. Linear regression equations were derived relating food consumption and body-weight to time. The mean food intake of each rat at a standard body-weight of $80 \mathrm{~g}$ was then calculated and an average value was obtained from the means for individual rats. The variability of food intake from the regression over five consecutive $4 \mathrm{~d}$ periods showed no trend with live weight during the experiment. Accordingly, all the variations in food intake from their regression on time were pooled to estimate the day-to-day variation of intake measured as the standard deviation from the regression, and a mean was calculated from the values for the individual rats of the group.

The rats grew on average at a linear rate of about $3.8 \mathrm{~g} / \mathrm{d}$ from 60 to $120 \mathrm{~g}$. This was associated with an average food intake of $8.4 \mathrm{~g} / \mathrm{d}$ at $80 \mathrm{~g}$ live weight with a day-to-day variation of intake of $\pm \mathrm{I} \cdot \circ \mathrm{g}$.

\section{Growth and food intake of $Z n$-deficient and pair-fed control rats}

Expt 2. To investigate the effects of $\mathrm{Zn}$ depletion on growth and food intake, twelve male rats were allocated to two equal groups, each of the rats of one group being pair-fed with a corresponding rat from the other. The pair-fed animals received 
the synthetic diet supplemented with $\mathrm{Zn}$ to $40 \mathrm{ppm}$. The rats of the experimental group received the supplemented diet $a d$ lib. for $5 \mathrm{~d}$ before transfer to the $\mathrm{Zn}$-deficient diet, which was given ad lib. Fig. I shows the mean growth of the two groups of rats. The graph for the pair-fed control animals has been displaced by i $d$ so that for each day the food intakes of the experimental rats correspond to those of the pair-fed group. Analysis of the food intake of the $\mathrm{Zn}$-deficient group between days I and 9 gave a mean food consumption of $8 \cdot 1 \mathrm{~g} / \mathrm{d}$ for an $80 \mathrm{~g}$ rat with a variation of intake of

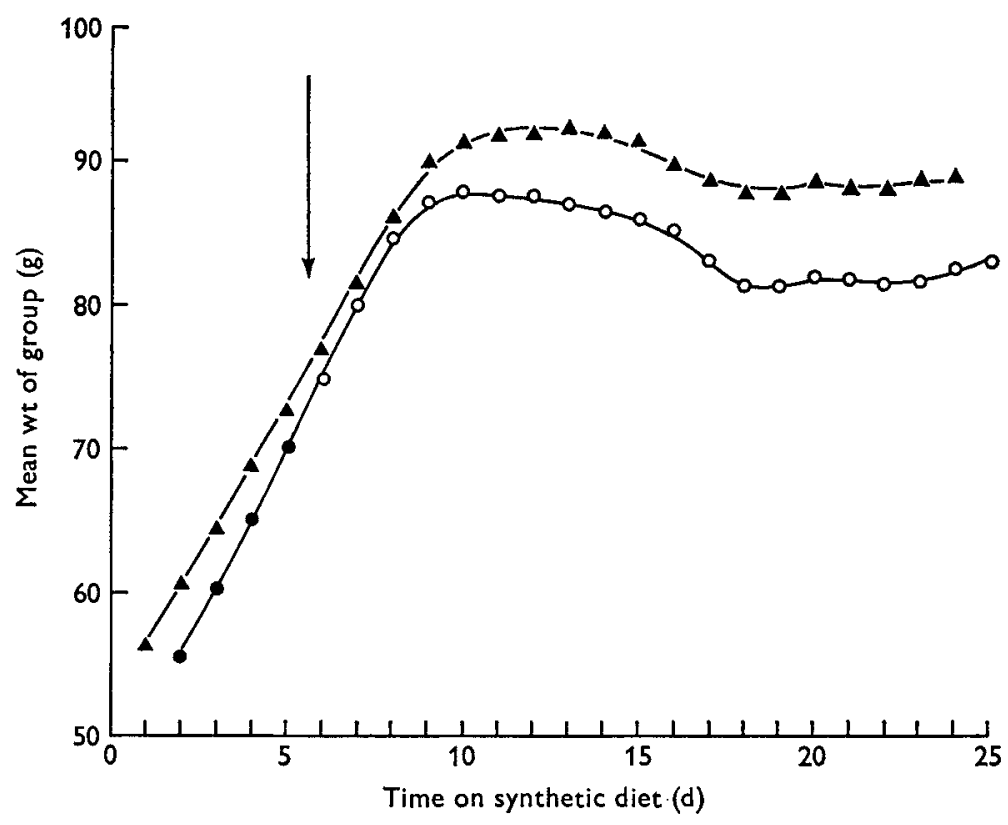

Fig. I. Mean growth of groups of $\mathrm{Zn}$-deficient and pair-fed control rats on the semi-synthetic diet. Closed symbols refer to periods when $\mathrm{Zn}$-supplemented diet was fed, open symbols to feeding of $\mathrm{Zn}$-deficient diet. $\mathrm{O}, \mathrm{Zn}$-deficient rats; $\Delta$, pair-fed rats; $\downarrow$, change of diet. The graph for the pair-fed animals has been displaced by I $d$ so that their daily food intakes correspond to those of the deficient rats.

$\pm 0.4 \mathrm{~g} / \mathrm{d}$. During days $\mathrm{II}-25$ inclusive, i.e. after growth had ceased owing to $\mathrm{Zn}$ deficiency, voluntary food intake averaged $4.8 \mathrm{~g} / \mathrm{d}$ with a variation of $\pm 2.6 \mathrm{~g} / \mathrm{d}$. When allowance was made for the greater initial weight of the control group, there was little to suggest that the control group fed a restricted quantity of diet adequate in $\mathrm{Zn}$ grew any faster than the deficient rats.

\section{Force-feeding of Zn-deficient and pair-fed control rats}

Expt 3. With the initial object of determining whether growth failure of rats given the $\mathrm{Zn}$-deficient diet was solely the consequence of poor food consumption, four $\mathrm{Zn}$-deficient male rats were force-fed with the $\mathrm{Zn}$-deficient diet to give a total food intake of $7.8 \mathrm{~g}$ dry matter/d. A similar group of rats receiving the $\mathrm{Zn}$-supplemented diet was pair-fed with the deficient group by the same force-feeding technique. Both 
groups appeared normal at the start of the force-feeding period and the pair-fed control rats remained so to the end of the experiment. However, after only 2 or $3 \mathrm{~d}$ at the elevated level of intake and before changes in weight could be assessed, the $\mathrm{Zn}$ deficient rats became severely ill and exhibited the following signs: lethargy, loss of co-ordination, bloating of the abdomen, diarrhoea, darker urine in smaller quantities than normal and accumulation of a red pigment on nose and paws. Prolonging the experiment would obviously have resulted in death, and force-feeding was discontinued after $3 \mathrm{~d}$.

\section{Effect of restricting intake}

Expt 4. Six male $\mathrm{Zn}$-deficient rats receiving the $\mathrm{Zn}$-deficient $20 \%$ protein diet were transferred from an ad lib. feeding regimen to a restricted intake $\left(5^{\circ} \circ \mathrm{g} / \mathrm{d}\right)$ after $22 \mathrm{~d}$ on the deficient diet.

Fig. 2 illustrates the effect of this change on the daily intake of one such rat. Taken as a group, the variability of food consumption fell from $\pm 2.4 \mathrm{~g} / \mathrm{d}$ on the $a d l i b$. regimen to $\pm 0.6 \mathrm{~g} / \mathrm{d}$ on the restricted intake.

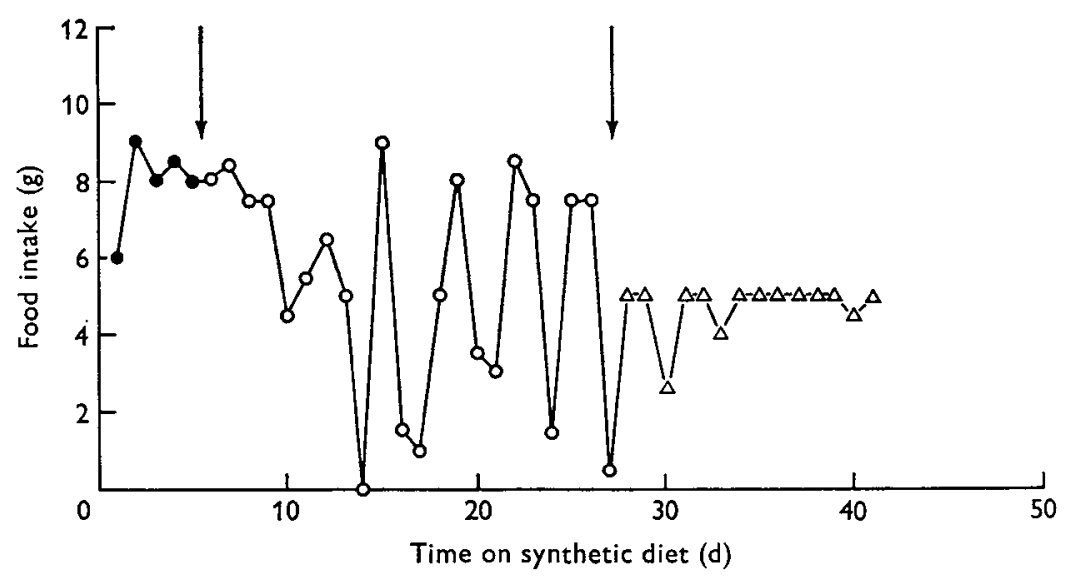

Fig. 2. Effect of $\mathrm{Zn}$ deficiency on the daily food intake of a rat on ad lib. or restricted feeding. Closed symbols represent diets containing $40 \mathrm{ppm} \mathrm{Zn}$, open symbols diets containing less than I ppm $\mathrm{Zn}$. O, ad lib. feeding; $\triangle$, restricted feeding at $5 \mathrm{~g} / \mathrm{d} ; \downarrow$, change of diet or regimen.

\section{Effect of low-protein diets}

Expt 5. The results of Expts 2, 3 and 4 suggested that the cyclical pattern of intake of $\mathrm{Zn}$-deficient rats might be caused by an accumulation of deleterious concentrations of metabolites after the consumption of a quantity of food equivalent to a normal daily intake. Such metabolites might cause depression of appetite until their elimination from the body. They could be nitrogenous metabolites of protein and, to test this hypothesis, the effect of reducing the protein content of the diet on the cycling of intake was investigated.

Six male weanling rats were raised on the $\mathrm{Zn}$-supplemented diet to a mean weight of $72 \mathrm{~g}$ and were then transferred to the Zn-deficient diet. Growth ceased after $4 \mathrm{~d}$, when the rats weighed approximately $85 \mathrm{~g}$. After $\mathrm{i} 4 \mathrm{~d}$ at approximately constant mean weight, the group were transferred to the $\mathrm{Zn}$-deficient diet, modified to contain only 
$5 \%$ protein. During the next $14 \mathrm{~d}$ the rats gained $5 \mathrm{~g}$ on average but then remained at constant weight for a further week. The $\mathrm{Zn}$ content of the $5 \%$ protein diet was approximately $0.6 \mathrm{ppm}$. The mean daily food intakes and their day-to-day variation for the

Table I. Expt 5. Effect of zinc and protein content of the diet on the food intake of rats and its day-to-day variation

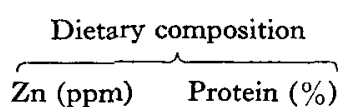

Zn (ppm) Protein (\%)

$\begin{array}{lr}40 & 20 \\ 0.9 & 20 \\ 0.6 & 5\end{array}$

Mean food intake $(g)$

$\begin{array}{ll}(a) & (b) \\ 7 \cdot 8^{\mathrm{a}} & 7 \cdot 8^{\mathrm{a}} \\ 5 \cdot 2^{\mathrm{b}} & 5 \cdot 6^{\mathrm{b}} \\ 6 \cdot \mathrm{I}^{\mathrm{c}} & 6 \cdot 6^{\mathrm{c}}\end{array}$

Mean* variation of daily intake (g)

$\begin{array}{cc}(a) & (b) \\ \pm I \cdot 2^{a} & \pm x \cdot 2^{a} \\ \pm 2 \cdot 4^{b} & \pm 2 \cdot 4^{b} \\ \pm 1 \cdot 3^{\mathrm{a}} & \pm \pm \cdot 3^{\mathrm{a}}\end{array}$

Columns $(a)$ and $(b)$ refer to the first and second investigations. The values are means for six and eight rats respectively.

* The variation was calculated for each rat and the group mean is presented (for details, see p. 1062).

The standard errors of the means were calculated for each of the values from the variations between the rats of a group, and the significance of the differences between groups was estimated by Student's $t$ test. Within a column, different superscripts indicate differences significant at the $5 \%$ level.

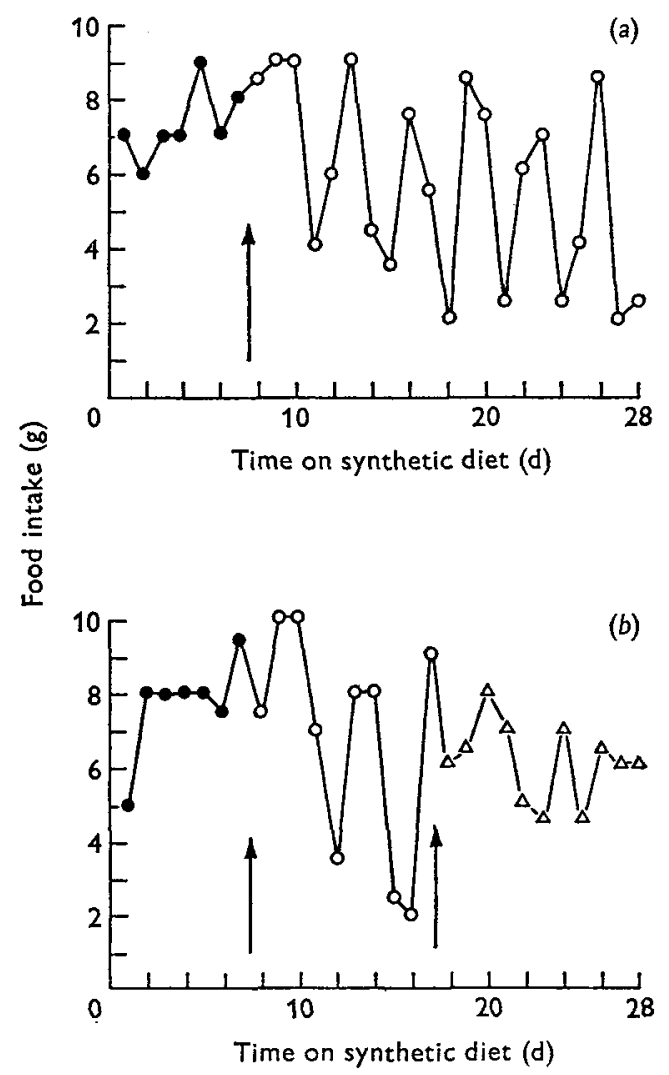

Fig. 3. Effect on daily food intakes of giving individual rats a diet (a) deficient in $\mathrm{Zn}$ and $(b)$ deficient in $\mathrm{Zn}$ and protein. Closed symbols refer to diets containing $40 \mathrm{ppm} \mathrm{Zn}$, open symbols to diets containing less than $\mathrm{x}$ ppm $\mathrm{Zn} .0,20 \%$ protein diets; $\triangle, 5 \%$ protein diets; $\uparrow$, change of diet. 
six rats for each of the experimental periods were calculated. The investigation was repeated with eight male weanling rats and the results from both investigations are shown in Table 1 . The daily food intakes of a typical $\mathrm{Zn}$-deficient rat and one deficient in both $\mathrm{Zn}$ and protein are shown in Fig. 3 .

In both of these investigations, transferring the rats from the deficient diet containing $20 \%$ protein to one containing $5 \%$ protein significantly increased their food intake and reduced its variability.

\section{Response of $Z n$-deficient rats to $Z n$-supplemented diets}

Expt 6. Male and female $\mathrm{Zn}$-deficient rats that had previously received the $\mathrm{Zn}$ deficient diet between 9 and $42 \mathrm{~d}$ from weaning were starved for $16 \mathrm{~h}$ and then given either the basal $\mathrm{Zn}$-deficient diet or the basal diet supplemented with $6 \mathrm{ppm} \mathrm{Zn}$. The food remaining uneaten by each rat was weighed at intervals during the first $24 \mathrm{~h}$. In

Table 2. Expt 6. Mean weight of food eaten at intervals during the first $24 h$ by six sinc-deficient rats given a diet supplemented with 6 ppm $Z n$ and five $Z n$-deficient rats given a diet containing $0.9 \mathrm{ppm} Z n$

\begin{tabular}{|c|c|c|c|}
\hline \multirow[b]{2}{*}{$\begin{array}{l}\text { Time after } \\
\text { feeding }(\mathrm{h})\end{array}$} & \multicolumn{2}{|c|}{$\begin{array}{c}\text { Cumulative mean food intake }( \pm \mathrm{SE}) \text { of } \\
\mathrm{Zn} \text {-deficient rats given }\end{array}$} & \multirow[b]{2}{*}{$\begin{array}{l}\text { Significance } \\
\text { of difference } \\
\qquad(P)\end{array}$} \\
\hline & Low- $\mathrm{Zn}$ diet & $\begin{array}{l}\text { Zn-supplemented } \\
\text { diet }\end{array}$ & \\
\hline I & $0.6 \pm 0.1$ & $I \cdot 0 \pm 0 \cdot I$ & $<0.05$ \\
\hline 3 & $1 \cdot 0 \pm 0.2$ & $2 \cdot 0 \pm 0.2$ & $<0.01$ \\
\hline 5 & $1 \cdot 9 \pm 0 \cdot 3$ & $3.0 \pm 0.2$ & $<0.02$ \\
\hline 7 & $2 \cdot 9 \pm 0.3$ & $3.9 \pm 0.2$ & $<0.05$ \\
\hline 24 & $6.4 \pm 0.5$ & $8 \cdot 4 \pm 0.7$ & $<0.05$ \\
\hline
\end{tabular}

four experiments with between four and eight rats in each group in each experiment, more of the $\mathrm{Zn}$-supplemented diet was eaten than of the $\mathrm{Zn}$-deficient diet; the difference between the groups became significant in 4-5 h. The results of one of these experiments in which a difference between the groups appeared after $\mathrm{I} h$ are given in Table 2.

\section{Discrimination between $Z n$-deficient and $Z n$-supplemented diets by $Z n$-deficient rats}

Expt 7. To investigate whether $\mathrm{Zn}$-deficient rats were able to discriminate between deficient diets and diets supplemented with $\mathrm{Zn}$, groups of four $\mathrm{Zn}$-deficient and four control rats, which had been receiving a $\mathrm{Zn}$-deficient or $\mathrm{Zn}$-supplemented diet respectively for up to 6 weeks, were simultaneously offered the $\mathrm{Zn}$-deficient diet and the same diet supplemented with $6 \mathrm{ppm} \mathrm{Zn}$. Control rats ate equal quantities of each diet, but $\mathrm{Zn}$-deficient rats at first selected almost entirely the $\mathrm{Zn}$-supplemented diet. Subsequently, as the $\mathrm{Zn}$-deficient rats became less deficient, their discrimination between the two diets ceased. After $6 \mathrm{~d}$ they were eating equal quantities of the two diets (Table 3 ). 
Table 3. Expt 7. Mean daily consumptions with their standard errors of zinc-deficient and $Z n$-supplemented diets offered together to four $Z n$-deficient rats for 6 consecutive $d$

$\begin{array}{ccc}\text { Day } & \begin{array}{c}\text { Wt of } \\ \text { Zn-supplemented } \\ \text { diet eaten }(\mathrm{g})\end{array} & \begin{array}{c}\text { Wt of } \\ \text { Zn-deficient } \\ \text { diet eaten }(\mathrm{g})\end{array} \\ \mathrm{I} & 6 \cdot 0 \pm \mathrm{I} \cdot 4 & 0 \cdot 6 \pm 0 \cdot 5 \\ 2 & 4 \cdot 3 \pm \mathrm{I} \cdot 6 & 0 \cdot 7 \pm 0 \cdot 4 \\ 3 & 5 \cdot 0 \pm \mathrm{r} \cdot 7 & 3 \cdot \mathrm{I} \pm \mathrm{I} \cdot 7 \\ 4 & 6 \cdot 1 \pm 2 \cdot 0 & \mathrm{I} \cdot 5 \pm \mathrm{I} \cdot 2 \\ 5 & 4 \cdot 6 \pm \mathbf{1} \cdot 5 & 2 \cdot 5 \pm \mathrm{I} \cdot 3 \\ 6 & 2 \cdot 8 \pm \mathbf{I} \cdot 3 & 2 \cdot 6 \pm \mathrm{I} \cdot 3\end{array}$

\section{Effect of protein-free diets on the change of appetite of $Z n$-deficient rats given $Z n$}

Expt 8. In this experiment we examined the effect of the presence or absence of dietary protein on the action of dietary $\mathrm{Zn}$ in causing a rapid increase in the food intake of $\mathrm{Zn}$-deficient rats, as described in Expt 6 .

$\mathrm{Zn}$-deficient and $\mathrm{Zn}$-supplemented diets containing no protein were prepared from the basal diets by replacing the egg albumen of the standard basal diet with maize starch.

In two experiments in which the conditions of Expt 6 were reproduced, eight $\mathrm{Zn}$-deficient rats were offered a $\mathrm{Zn}$-deficient, protein-free diet and eight a $\mathrm{Zn}$ supplemented, protein-free diet. The subsequent food intakes of the two groups were identical, in contrast to the results reported in Expt 6 with diets containing protein.

\section{The ability of rats to discriminate between protein-free diets deficient or adequate in $Z n$}

Expt 9. In this experiment an investigation was made of the effect of the absence of protein on the ability of rats to discriminate between the $\mathrm{Zn}$-deficient and $\mathrm{Zn}$-supplemented diets described in Expt 7.

In two experiments in which the conditions of Expt 7 were reproduced, $\mathrm{Zn}$-deficient rats were offered the choice of two protein-free diets, one $\mathrm{Zn}$-deficient and one $\mathrm{Zn}$ supplemented. They ate equal quantities of each diet, in contrast to the results reported in Expt 7 with diets containing protein, where the $\mathrm{Zn}$-supplemented diet was selected.

\section{DISCUSSION}

Incipient $\mathrm{Zn}$ deficiency in the young rat was characterized by a cessation of growth followed by an extended period during which body-weight varied very little. Concurrently with this growth failure, daily food intake fell and this depression of food intake was sufficient to inhibit virtually all growth of pair-fed control animals given the same diet with supplementary $\mathrm{Zn}$. Force-feeding of the deficient animal to raise its intake to that of a normal animal offered a $\mathrm{Zn}$-supplemented diet $a d l i b$. rapidly induced signs of severe disorder. Reduction of the protein content of the $\mathrm{Zn}$-deficient diet from 
20 to $5 \%$ significantly increased food intake and reduced its variation to that of a normal rat, but this was not associated with a stimulation of growth. It is clear that $\mathrm{Zn}$ deficiency results in metabolic lesions as well as loss of appetite. Nevertheless a fall in food intake is highly characteristic of $\mathrm{Zn}$ deficiency. In the experiment described by Williams \& Mills (1970) groups of male rats were fed diets containing 3, 6, 9 or 12 $\mathrm{ppm} \mathrm{Zn}$. Analysis of the food intake of these rats when they weighed $80 \mathrm{~g}$ and the dayto-day variation in their intake by the methods described in Expt I showed that there was a significant trend of increasing food consumption and decreasing variation in daily food intake with increase in $\mathrm{Zn}$ content of the diets. Furthermore, prevention of elevated intakes by restricted feeding eliminated the troughs of food consumption normally associated with $\mathrm{Zn}$ deficiency. The hypothesis is advanced that the cyclical pattern of food intake of the $\mathrm{Zn}$-deficient animal results from appetite being regulated by corresponding rises and falls in the concentration of one or more metabolites. It is postulated that after elevated food intakes these metabolites accumulate, reaching deleterious concentrations which inhibit appetite.

The reduction of the day-to-day range of intake of food by rats given the $5 \%$ protein diet suggests a relationship between the range and protein intake. In addition, the signs produced by force-feeding the deficient rats were similar to those described by Forbes \& Vaughan (1954) when rats were force-fed a diet low in methionine. However, these authors found similar signs with diets low in histidine and some of these signs, particularly the appearance of porphyrins on the nose and feet, have been reported in deficiencies of nicotinic acid (Krehl, Sarma, Teply \& Elvehjem, 1946) and of pantothenic acid (Chick, Macrae \& Worden, 1940). Other workers have also shown that $\mathrm{Zn}$ deficiency produced changes in oxidation and incorporation of methionine into protein (Hsu, Anthony \& Buchanan, 1969), in the incorporation of glycine into glutathione (Hsu, Anthony \& Buchanan, 1968) and in the pattern of plasma and liver free amino acids (J. Quarterman \& E. Florence, unpublished observations). It is possible that the regulatory metabolites of importance in the above hypothesis are derived from protein.

The addition of microgram quantities of $\mathrm{ZnSO}_{4}$ to a $\mathrm{Zn}$-deficient diet produced large increases in food intake within $4 \mathrm{~h}$. That these small amounts could be detected by rats was demonstrated by their almost complete avoidance of the $\mathrm{Zn}$-deficient diet when they had a $\mathrm{Zn}$-supplemented, but otherwise identical, diet available. In relation to this, it is interesting that Henkin \& Bradley (1969) found that thiolcontaining drugs such as D-penicillamine inhibited taste acuity for $\mathrm{NaCl}$ in some human patients and that this inhibition could be reversed by the addition of $\mathrm{Zn}$ or $\mathrm{Cu}$ to the diet. They suggest that there is a relationship between free sulphydryl groups and metals in the biochemistry of taste. They also describe the clinical history of a patient with myeloma who had lost her sense of taste. She had a low plasma $\mathrm{Zn}$ level, and after four daily doses of $60 \mathrm{mg} \mathrm{Zn}$ her taste acuity had returned to normal, but it decreased rapidly when $\mathrm{Zn}$ administration was stopped. Rats may be able to taste $6 \mathrm{ppm} \mathrm{Zn}$, or the presence of $\mathrm{Zn}$ may affect their ability to taste other components of the diet. If the selection of diets containing $\mathrm{Zn}$ is based not on taste but on some other physiological response to $\mathrm{Zn}$, this response must be rapid since, when the $\mathrm{Zn}$-supplemented diet 
was available, the low- $\mathrm{Zn}$ diet was often rejected before significant amounts (about $0 \cdot 1 \mathrm{~g})$ had been eaten.

In the absence of protein, the ability of rats to respond quickly in appetite and in dietary discrimination to very small amounts of dietary $\mathrm{Zn}$ was lost. However, the evidence suggesting that the lesions of $\mathrm{Zn}$ deficiency are associated with protein metabolism remains circumstantial and inconclusive and further work is needed to elucidate the nature of the relationship of $\mathrm{Zn}$ and protein to growth and appetite.

We wish to acknowledge the able technical assistance of Miss M. Nicol and MrW. R. Humphries.

\section{REFERENCES}

Chick, H., Macrae, T. F. \& Worden, A. N. (1940). Biochem. $\mathscr{F} .34,580$.

Forbes, R. M. \& Vaughan, L. (I954). F. Nutr. 52, 25.

Henkin, R. I. \& Bradley, D. F. (1969). Proc. natn. Acad. Sci. U.S.A. 62, 30.

Hsu, J. M., Anthony, W. L. \& Buchanan, P. J. (1968). Proc. Soc. exp. Biol. Med. 127, ro48.

Hsu, J. M., Anthony, W. L. \& Buchanan, P. J. (1969). F. Nutr. 97, 279.

Humphries, W. R. \& Quarterman, J. (1968). Proc. Nutr. Soc. 27, 54A.

Krehl, W. A., Sarma, P. S., Teply, L. J. \& Elvehjem, C. A. (1946). F. Nutr. 31, 85 .

Quarterman, J., Williams, R. B. \& Humphries, W. R. (1970). Br. F. Nutr, 24, 1049.

Williams, R. B. \& Mills, C. F. (1970). Br. F. Nutr. 24, 989. 